\title{
The Effect of Specialization on Postoperative Complications in Thyroid Surgery
}

\author{
Yasin Tosun, ๑ Kenan Çetin, ๑ Hasan Ediz Sıkar, ๑ Ozan Akıncı
}

Department of General Surgery, İstanbul Kartal Dr. Lütfi Kırdar City Hospital, İstanbul, Turkey

Submitted: 20.06 .2020 Accepted: 14.09.2020

Correspondence: Yasin Tosun İstanbul Kartal Dr. Lütfi Kırdar Şehir Hastanesi, Genel Cerrahi Kliniği, İstanbul, Turkey

E-mail: yasintosun@gmail.com

arista

Keywords: Postoperative complications; specialization; thyroidectomy. This work is licensed under a Creative Commons
Atribution-NonCommercial 4.0 International Licens

\begin{abstract}
Objective: The relationship between the surgeon's experience/volume of performed operations and postoperative results of thyroid surgery is a pressing issue that has been widely discussed in recent publications. This study aimed to compare the complication rates in thyroidectomy operations performed before and after specialization and evaluate the effect of specialization on the outcomes of thyroid surgeries.
\end{abstract}

Methods: The study included patients who had undergone thyroidectomy with or without neck dissection due to benign or malign thyroid diseases in a single tertiary reference hospital between April 2013 and March 2017. The patients were divided into two groups: those who were operated on before specialization (BS) and after specialization (AS). Age, gender, operation type, postoperative hypocalcemia, incidental parathyroidectomy, recurrent laryngeal nerve (RLN) injury, and postoperative bleeding or hematoma were compared between the groups.

Results: Of the thyroid patients, 776 were operated on (367 (47\%) and 409 (53\%) of the BS and AS groups, respectively). No significant difference was found between the two groups regarding the postoperative $\mathrm{Ca}^{2+}$ level, while the parathormone was significantly lower in the $B S$ group ( $p=0.2$ and $p=0.02$, respectively). In addition, postoperative transient hypocalcemia was significantly less common in the AS group $(p<0.00 \mathrm{I})$. The incidental parathyroidectomy rate was significantly higher in the BS group $(p<0.01)$. Postoperative transient hoarseness developed in $15(4 \%)$ patients in the BS group and in $2(0.5 \%)$ patients in the AS group. Twelve patients had unilateral vocal cord paralysis, all of whom were in the BS group $(p<0.01)$. No significant difference exists between the groups regarding bleeding $(p=0.5)$.

Conclusion: This study indicated that specialization in thyroid surgery significantly reduced complications (e.g., hypocalcemia, incidental parathyroidectomy, and RLN injury).

\section{INTRODUCTION}

The diseases of the thyroid glands are the second most common endocrine diseases in the general population. ${ }^{[1,2]}$ Currently, thyroid gland surgeries are widely applied in thyrotoxicosis, thyroid cancer, and relieving cosmetic problems or pressure symptoms in multinodular goiter ${ }^{[3]}$ The scope of resection for benign thyroid diseases is still controversial although total thyroidectomy is the standard treatment in malignant thyroid diseases. ${ }^{[4,5]}$

Thyroid surgery, previously with high mortality and morbidity rates, has recently become a safe procedure widely applied by many surgeons due to technological developments (e.g., laryngeal nerve monitoring). ${ }^{[6]}$ Recurrent laryngeal nerve (RLN) injury and hypocalcemia are the most significant and dreaded complications of thyroid surgery because they may create lifetime handicaps in patients. [7] Several studies have shown that high-volume centers and specialization are associated with low complication rates. ${ }^{[8]}$ Reducing the mortality from $40 \%$ to $0.5 \%$ after more than 5,000 surgeries, Theodor Kocher, one of the pioneers of thyroid surgery, is the first high-volume endocrine surgeon to demonstrate that surgical training and techniques reduce complications. ${ }^{[9]}$ Growing confidence is evident that general surgeons' specialization into more specific branches such as endocrine surgery improves the outcome of rare diseases. ${ }^{[10]}$

In light of significant data, specialization in thyroid surgery has become more common and recognized. This study aimed to compare the complication rates in thyroidectomy operations performed before and after specialization and evaluate the effect of specialization on the outcomes of thyroid surgeries.

\section{MATERIALS AND METHODS}

\section{Study design}

The study was designed as a retrospective cohort study. The study included patients who had undergone thyroid- 
ectomy with or without neck dissection due to benign or malign thyroid diseases in a single tertiary reference hospital between April 2013 and March 2017. The study protocol was approved by the institutional review board (approval number: 2020/5 I4/178/23).

\section{Study cohorts}

The general surgery clinic of this study was transformed into a specialized center beginning in April 2014. The patients were divided into two groups: those who were operated on before specialization (BS, April 20I3-March 2014) and after specialization (AS, April 20I4-March 2016). Those in the BS group were operated on by II general surgeons, while those in the AS group were operated on by three general surgeons specializing in thyroid surgeries.

\section{Inclusion and exclusion criteria}

The study included patients $>18$ years operated on in general surgery clinics. Those $<18$ years, operated on in pediatric surgery or otolaryngology clinics, and not followed up by the clinic of this study in the postoperative period were excluded.

\section{Data}

The data were obtained from patient files, surgery reports, and pathology reports. Age, gender, operation type, postoperative hypocalcemia, incidental parathyroidectomy, RLN injury, and postoperative bleeding or hematoma were compared in both groups.

\section{Evaluation and classification of complications}

Calcium levels $<8.4 \mathrm{mg} / \mathrm{dL}$ were considered as the cutoff for the diagnosis of hypocalcemia. Hypocalcemia with a need for $\mathrm{Ca}^{2+}$ replacement therapy of $<12$ months was considered as temporary, and those otherwise were considered as permanent hypocalcemia. Incidental parathyroidectomy was defined as the accidental removal of one or more parathyroid glands during elective thyroid surgery and its inclusion in pathology material. ${ }^{[1]}$ Perioperative nerve monitoring records in the surgical reports and postoperative vocal cord examinations were used for the RLN injury. Vocal cord examination was performed in the ear, nose, and throat clinic for patients with postoperative hoarseness. The cases with normal vocal cord examination and hoarseness for $<6$ months were categorized as temporary hoarseness. Those with hoarseness for $>6$ months, vocal cord dysfunction, and vocal cord paralysis (VCP) were categorized as permanent hoarseness. While evaluating the postoperative bleeding data, only cases that required reexploration and had pressure signs were considered.

\section{Statistical analysis}

Statistical analysis was done using the Statistical Package for the Social Sciences (version 24.0, IBM Corp., Armonk,
NY, USA). Descriptive statistical methods (median, frequency, percent, minimum, and maximum) were used to present the data. Pearson chi-square test was used to compare qualitative data, and Fisher's exact test was applied when the number of subgroups was low. The normal distribution of quantitative data was assessed by the Kolmogorov-Smirnov and Shapiro-Wilk tests. The quantitative data without normal distribution were compared with the Mann-Whitney $U$ test. A $p$ value of $<0.05$ was considered statistically significant.

\section{RESULTS}

Of the patients, 776 thyroid patients were operated on (367 (47\%) and 409 (53\%) before specialization (BS) and after specialization (AS), respectively). Moreover, 590 (76\%) and $186(24 \%)$ of the patients were females and males, respectively. The average age was $49.3 \pm 12.8$ and $48.1 \pm 12.4$ in the BS and AS groups, respectively. No significant difference between the groups exists in terms of age and gender. However, a significant difference was noted in terms of the extent of thyroidectomy (lobectomy vs. total thyroidectomy, $\mathrm{p}<0.00 \mathrm{I}$; Table I). The rate of total thyroidectomy was higher in the BS group ( $73.6 \%$ vs. $57.5 \%)$, while central and lateral neck dissections due to malignant thyroid diseases were more common in the AS group (7.3\% vs. $3.5 \%)$.

No significant difference in the postoperative $\mathrm{Ca}^{2+}$ level was found between the two groups, while the parathyroid hormone was significantly lower in the BS group $(p=0.2$ and $p=0.02$, respectively). Postoperative transient hypocalcemia developed in 61 (16.6\%) and 36 (8.8\%) patients in the BS and AS groups, respectively. Postoperative transient hypocalcemia was significantly less common in the AS group $(p<0.001)$. In the pathology specimens, incidental parathyroidectomy was found in 88 (24.6\%) and $28(6.8 \%)$ of the patients in the BS and AS groups, respectively. However, the rate was significantly higher in the BS group ( $p<0.01$; Table 2$)$.

Postoperative transient hoarseness developed in 15 (4\%) and two $(0.5 \%)$ of the patients in the BS and AS groups, respectively. Twelve patients, all of whom were in the BS group, had unilateral VCP $(p<0.01)$.

Reexploration was required due to bleeding in two $(0.5 \%)$ and one $(0.2 \%)$ patient in the BS and AS groups, respectively. No significant difference regarding bleeding exists between the groups $(p=0.5)$.

\section{DISCUSSION}

Surgical intervention provides effective treatment with minimal complication and mortality. The concept of specialization, introduced in all sciences in the second half of the twentieth century, was also considered in thyroid surgery as an important branch of general surgery. The relationship between the surgeon's experience/volume of performed operations and the postoperative results of 
Table I. The comparison of demographic data and surgical interventions for the BS and AS groups

\begin{tabular}{|c|c|c|c|}
\hline Parameters & BS group $(n=367)$ & AS group $(n=409)$ & $\mathbf{p}$ \\
\hline Age, years, mean $\pm S D$ & $49.3 \pm 12.8$ & $48.1 \pm 12.4$ & 0.830 \\
\hline Male gender, n (\%) & $125(34.1)$ & $138(33.7)$ & 0.920 \\
\hline Lobectomy, n (\%) & $97(26.4)$ & $174(42.5)$ & \\
\hline Right & 37 & 94 & \\
\hline Left & 60 & 80 & \\
\hline Total thyroidectomy, n (\%) & $270(73.6)$ & $235(57.5)$ & $<0.001$ \\
\hline$+C N D$ & 9 & 21 & \\
\hline$+\mathrm{FND}$ & 2 & 6 & \\
\hline +MRND & 2 & 3 & \\
\hline Pathology results, n (\%) & & & 0.020 \\
\hline Benign & $279(76)$ & $28 \mathrm{I}(68.7)$ & \\
\hline Malignant/mic & $88(24) / 34(9.3)$ & $128(31.3) / 52(12.7)$ & \\
\hline
\end{tabular}

*mic: <10 mm microcancers. BS: Before specialization; AS: After specialization; SD: Standard deviation, CND: Central neck dissection; FND: Functional neck dissection; MRND: Modified radical neck dissection.

Table 2. The comparison of complication rates in the BS and AS groups

\begin{tabular}{|c|c|c|c|}
\hline Complications & BS group $(n=367)$ & AS group $(n=409)$ & $\mathbf{p}$ \\
\hline $\mathrm{Ca}^{+2}, \mathrm{mg} / \mathrm{dL}$, mean $\pm \mathrm{SD}^{*}$ & $8.5 \pm 1.1$ & $8.7 \pm 0.9$ & 0.200 \\
\hline PTH, mean \pm SD* $^{*}$ & $30 \pm 27$ & $4 I \pm 29$ & 0.020 \\
\hline Incidental parathyroidectomy, n (\%) & $88(24.6)$ & $28(6.8)$ & $<0.001$ \\
\hline Hypocalcemia, n (\%) & $65(17.7)$ & $39(9.5)$ & $<0.001$ \\
\hline Temporary & $61(16.6)$ & $36(8.8)$ & \\
\hline Permanent & $4(1.1)$ & $3(0.7)$ & \\
\hline Hoarseness, n (\%) & $15(4.1)$ & $2(0.5)$ & 0.002 \\
\hline Temporary & $15(4)$ & $2(0.5)$ & \\
\hline VCD or VCP in vocal cord examination & $12(3.3)$ & 0 & \\
\hline Permanent & $3(0.8)$ & 0 & \\
\hline Reexploration due to bleeding, n (\%) & $2(0.5)$ & I (0.02) & 0.500 \\
\hline
\end{tabular}

thyroid surgery is a pressing issue that has been widely discussed in recent publications. ${ }^{[1,3,4,6,8,10]}$ Several studies reported that surgical case series performed by high-volume thyroid surgeons supported this relationship in thyroid surgery. ${ }^{[1,4,12,13]}$ Surgeon volume has also been shown to affect the outcome for patients with more serious diagnoses such as thyroid cancer. ${ }^{[1]}$ The surgeon's experience was found to influence not only the complications but also the parameters such as the length of hospital stay and cost. $[1,3,8]$ The most common complications of thyroid surgery are bleeding, RLN injury, the injury of the external branch of the superior laryngeal nerve, esophageal injury, tracheal injury, infection, and hypocalcemia. ${ }^{[14]}$

The most common complication after thyroidectomy is hypocalcemia with a frequency of $20 \%-30 \% .^{[15]}$ Before or after specializing in thyroid surgeries, the rate of hypocalcemia following thyroidectomy operations was lower than those reported in other studies because lobectomies were also included in this study. Consequently, postoperative hypocalcemia resulting from surgical injury or accidental removal of the parathyroid gland is mostly seen in patients with central or lateral dissection accompanying thyroidectomy and those with Graves' disease. ${ }^{[15,16]}$ Meltzer et al. ${ }^{[17]}$ reported that the rate of hypocalcemia was significantly lower in surgeries performed by specialized and high-volume surgeons. Hauch et al. ${ }^{[4]}$ have compared the rates of hypocalcemia after thyroidectomy operations performed by low, medium, and high-volume surgeons, and showed that the rate significantly decreased with experienced thyroid surgeons. Similarly, the rate of transient hypocalcemia after thyroidectomy operations performed in the postspecialization period was significantly lower than that in the prespecialization period $(\mathrm{p}<0.00 \mathrm{I})$.

Although some studies reported that incidental parathyroidectomy did not affect postoperative hypocalcemia, several studies have shown that the incidence of transient hypocalcemia was higher in patients who had undergone one or more incidental parathyroidectomies. ${ }^{[18-2 \mid]}$ Total 
thyroidectomy, the extrathyroidal extension of the tumor, and thyroiditis have been identified as risk factors for incidental parathyroidectomy. ${ }^{[18,22]}$ The rates of incidental parathyroidectomy have been reported to vary between $6 \%$ and $20 \% .{ }^{[19,22]}$ In addition, Sosa et al. ${ }^{\left[{ }^{[1]}\right.}$ reported that incidental parathyroidectomy rates were lower for high-volume surgeons. Similarly, the rate of incidental parathyroidectomy in this study was significantly lower in the AS compared with the BC group $(\mathrm{p}<0.0 \mathrm{I})$.

Thyroid cancer, Graves' disease, and recurrent goiter significantly increase the risk of RLN injury. ${ }^{[23]}$ The intraoperative RLN audiovisual monitoring has reduced the risk of nerve injury with advances in technology. The rate of RLN injury has been reported to be $5 \%-11 \%$, although it is $<1 \%$ in thyroidectomies performed by experienced surgeons. [15,24] Thus, the lower rate of RLN injury was because this study was retrospective and that the vocal cord examination was performed only in patients with hoarseness. Kandil et al. ${ }^{[2]}$ reported that the risk of RLN injury was significantly lower in surgeries performed by high- compared with low-volume surgeons. In contrast, Hauch et al. ${ }^{[4]}$ showed no significant difference between the surgeries performed by low- and high-volume surgeons in terms of VCP. Moreover, all of the patients who had VCP in this study were in the BS group. In addition, the AS group was significantly superior to the BS group regarding the rate of RLN injury $(p<0.01)$.

Bleeding is a life-threatening complication after thyroid surgery. Albeit rarely, bleeding may require reexploration because it may cause pressure on the airway, block venous and lymphatic drainage, and result in laryngopharyngeal edema. The frequency of bleeding was $0.36 \%-4.3 \%$. [25] Several studies have suggested that the high-volume and specialized surgeons significantly reduce bleeding and hematoma resulting from thyroidectomy. ${ }^{[1,2,4,17,26]}$ However, no significant difference regarding the rate of bleeding that required reexploration was found between the $A S$ and $B S$ groups in this study $(p=0.500)$.

Retrospective design and data from a single center were the major limitations of this study. However, it is motivating and encouraging for young endocrine surgeons because the positive results of the specialization process that has recently started were shown.

\section{CONCLUSION}

This study indicated that specialization in thyroid surgery significantly reduced complications such as hypocalcemia, incidental parathyroidectomy, and RLN injury. Therefore, specialization in endocrine surgery contributes to the training of more experienced surgeons with more reliable outcomes.

\section{Ethics Committee Approval}

Approved by the local ethics committee.

Informed Consent

Retrospective study.

\section{Peer-review}

Internally peer-reviewed.

Authorship Contributions

Concept: Y.T., K.Ç.; Design: K.Ç., H.E.S.; Supervision: Y.T., O.A.; Fundings: K.Ç., H.E.S.; Materials: O.A., Y.T.; Data: O.A., Y.T.; Analysis: K.Ç., H.E.S.; Literature search: O.A., Y.T.; Writing: O.A., Y.T., K.Ç.; Critical revision: K.Ç., H.E.S.

Conflict of Interest

None declared.

\section{REFERENCES}

1. Sosa JA, Bowman HM, Tielsch JM, Powe NR, Gordon TA, Udelsman R. The importance of surgeon experience for clinical and economic outcomes from thyroidectomy. Annals of surgery 1998;228:320-30.

2. Kandil E, Noureldine SI, Abbas A, Tufano RP. The impact of surgical volume on patient outcomes following thyroid surgery. Surgery 2013;154:1346-52.

3. Watkin D. Who should do thyroid surgery? Hosp Med 2000;61:756-7.

4. Hauch A, Al-Qurayshi Z, Randolph G, Kandil E. Total thyroidectomy is associated with increased risk of complications for low-and high-volume surgeons. Annals of surgical oncology 2014;21:3844-52.

5. Delbridge L. Total thyroidectomy: the evolution of surgical technique. ANZ J Surg 2003;73:761-68.

6. Ayala MA, Yencha MW. Outpatient thyroid surgery in a low-surgical volume hospital. World journal of surgery 2015;39:2253-8.

7. Bergenfelz A, Jansson S, Kristoffersson A, Mårtensson H, Reihnér E, Wallin $\mathrm{G}$, et al. Complications to thyroid surgery: results as reported in a database from a multicenter audit comprising 3,660 patients. Langenbeck's Archives of Surgery 2008;393:667-73.

8. González-Sánchez C, Franch-Arcas G, Gómez-Alonso A. Morbidity following thyroid surgery: does surgeon volume matter? Langenbeck's archives of surgery 2013;398:419-22.

9. Dzodic R, Santrac N, Markovic I, Buta M, Goran M. Complications in Thyroid Surgery. In: Parameswaran R, Agarwal A, editors. Evidence-Based Endocrine Surgery. Singapore: Springer; 2018. p. 187-99.

10. Pasieka JL. The surgeon as a prognostic factor in endocrine surgical diseases. Surgical oncology clinics of North America 2000;9:13-20.

11. Sippel RS, Ozgul O, Hartig GK, Mack EA, Chen H. Risks and consequences of incidental parathyroidectomy during thyroid resection. Aust N Z J Surg 2007;77:33-6.

12. Stavrakis AI, Ituarte PH, Ko CY, Yeh MW. Surgeon volume as a predictor of outcomes in inpatient and outpatient endocrine surgery. Surgery 2007;142:887-99.

13. Morton RP, Gray L, Tandon DA, Izzard M, McIvor NP. Efficacy of neck dissection: are surgical volumes important? Laryngoscope 2009;119:1147-52.

14. Altaca G, Onat D. Tiroidektomi ve komplikasyonları. In: Sayek İ, editor. Temel Cerrahi. 3rd ed. Ankara: Güneş Kitabevi; 2004. p. 1621-30.

15. Christou N, Mathonnet M. Complications after total thyroidectomy. J Visc Surg 2013;150:249-56.

16. Ignjatović $\mathrm{M}, \mathrm{Cuk} \mathrm{V}, \mathrm{Ozegović} \mathrm{A}$, Cerović $\mathrm{S}$, Kostić Z, Romić P. Early complications in surgical treatment of thyroid diseases: analysis of 2100 patients. Acta Chir Iugosl 2003;50:155-75.

17. Meltzer C, Klau M, Gurushanthaiah D, Tsai J, Meng D, Radler L, 
et al. Surgeon Volume in Thyroid Surgery: Surgical Efficiency, Outcomes, and Utilization. Laryngoscope 2016;126:2630-39.

18. Sitges-Serra A, Ruiz S, Girvent M, Manjón H, Dueñas JP, Sancho JJ. Outcome of protracted hypoparathyroidism after total thyroidectomy. Br J Surg 2010;97:1687-95.

19. Erbil Y, Barbaros U, Temel B, Turkoglu U, Işsever H, Bozbora A, et al. The impact of age, vitamin $\mathrm{D}(3)$ level, and incidental parathyroidectomy on postoperative hypocalcemia after total or near total thyroidectomy. Am J Surg 2009;197:439-46.

20. Kamer E, Unalp HR, Erbil Y, Akguner T, Issever H, Tarcan E. Early prediction of hypocalcemia after thyroidectomy by parathormone measurement in surgical site irrigation fluid. Int J Surg 2009;7:466-71.

21. Rajinikanth J, Paul MJ, Abraham DT, Ben Selvan CK, Nair A. Surgical Audit of Inadvertent Parathyroidectomy During Total Thyroidectomy: Incidence, Risk Factors, and Outcome. Medscap J Med 2009;11:29.
22. Sakorafas GH, Stafyla V, Bramis C, Kotsifopoulos N, Kolettis T, Kassaras G. Incidental parathyroidectomy during thyroid surgery: an underappreciated complication of thyroidectomy. World J Surg 2005;29:1539-43.

23. Chiang FY, Wang LF, Huang YF, Lee KW, Kuo WR. Recurrent laryngeal nerve palsy after thyroidectomy with routine identification of the recurrent laryngeal nerve. Surgery 2005;137:342-7.

24. Lal G, Clark OH. Thyroid, parathyroid and adrenal. In: Brunicardi FC, Andersen DK, editors. Schwartz's Principles of Surgery. 10th ed. USA: McGraw Hill; 2014. p. 1521-96.

25. Pontin A, Pino A, Caruso E, Pinto G, Melita G, Maria DP, et al. Postoperative Bleeding after Thyroid Surgery: Care Instructions. Med Bull Sisli Etfal Hosp 2019;53:329-36.

26. Dehal A, Abbas A, Al-Tememi M, Hussain F, Johna S. Impact of surgeon volume on incidence of neck hematoma after thyroid and parathyroid surgery: ten years' analysis of nationwide in-patient sample database. Am Surg 2014;80:948-52.

\section{Tiroid Cerrahisinde Branşlaşmanın Ameliyat Sonrası Komplikasyonlar Üzerine Etkisi}

Amaç: Cerrahın tecrübe ve volümü ile tiroid cerrahisinin ameliyat sonrası sonuçları arasındaki ilişki son yıllarda literatürde yaygın olarak tartışılan güncel bir konudur. Bu çalışmamızda, kliniğimizde branşlaşma öncesi ve sonrası dönemlerde gerçekleştirilmiş olan tiroidektomi ameliyatlarının komplikasyon oranlarını karşılaştırmayı ve branşlaşmanın tiroid cerrahisi sonuçları üzerine etkisini değerlendirmeyi amaçladık.

Gereç ve Yöntem: Çalışma, Nisan 20I3-Mart 2017 tarihleri arasında tek bir üçüncü basamak referans hastanede benign ve malign tiroid hastalıkları nedeniyle boyun diseksiyonu olan veya olmayan tiroidektomi yapılmıs hastaları içermektedir. Hastalar kliniğimizde branşlaşma öncesi (BÖ grubu) ve branşlaşma sonrası (BS grubu) olmak üzere iki gruba ayrıldı. Gruplar yaş, cinsiyet, operasyon türü, ameliyat sonrası hipokalsemi, insidental paratiroidektomi, rekürren larengeal sinir yaralanması ve ameliyat sonrası kanama/hematom açısından karşılaştıııldı.

Bulgular: Branşlaşmaya gidilmeden önceki (BÖ) yıllarda 367 (\%47), branşlaşma sonrası (BS) iki yılda 409 (\%53) olmak üzere toplam 776 tiroid hastası ameliyat edildi. Gruplar arasında $\mathrm{Ca}^{2+}$ açısından anlamlı fark olmadığı, PTH seviyesinin ise Grup BÖ'de anlamlı ölçüde daha düşük olduğu gözlendi (sırasıyla, $p=0.2$ ve $p=0.02$ ). Grup BS'de anlamlı ölçüde daha az ameliyat sonrası geçici hipokalsemi geliştiği görüldü ( $p<0.00 \mathrm{I}$ ). İnsidental paratiroidektomi oranı BÖ grubunda anlamlı ölçüde daha yüksekti ( $p<0.01)$. Grup BÖ'de 15 (\%4), Grup BS'de 2 (\%0.5) hastada ameliyat sonrası geçici ses kısıklı̆̆ı geliştiği görüldü. Çalışmamızda toplam 12 hastada tek taraflı vokal kord paralizisi geliştiği ve bu olguların tamamının Grup BÖ’de olduğu görüldü $(p<0.0 I)$. Gruplar arasında kanama açısından istatistiksel anlamlı bir fark yoktu $(p=0.5)$.

Sonuç: Bu çalışmadan elde ettiğimiz veriler tiroid cerrahisinde branşlaşmanın hipokalsemi, insidental paratiroidektomi ve rekürren larengeal sinir yaralanması komplikasyonlarını anlamlı ölçüde azalttığını göstermektedir.

Anahtar Sözcükler: Ameliyat sonrası komplikasyonlar; branşlaşma; tiroidektomi. 